\title{
Growth, Chlorophyll, Yield and Tubers Chemical Composition, and Quality Characters of Potato Cv. Spunta as Affected by Planting Dates and Irrigation Regimes
}

\author{
Noura Mohammed Taha ${ }^{1}$, Alaa El-Den Hussein Roshdy ${ }^{2}$
}

\begin{abstract}
During the two successive seasons of 2018/2019 and 2019/2020 the feild experiment was conducted in AlAqwaz, Giza Governorate, aiming to study the effect of three planting dates $\left(1^{\text {st }}\right.$ of December, $15^{\text {th }}$ of December and $1^{\text {st }}$ of January) and three irrigation regimes $(50,75$ and $100 \%$ of the irrigation requirements for each of the selected planting date) on the vegetative growth, chlorophyll, tuber chemical composition (nitrogen, potassium, phosphorus and calcium), tuber yield and its quality parameters (specific gravity, dry matter, protein and starch). The results showed that there were significant effects for the treatments of planting dates and irrigation regimes on all of the studied characters, in both seasons of study. Also, the effect of irrigation regems was more pronounced comparing with the effect of plantting dates on studied characters. However, The planting on the first of December and/or the irrigation with $100 \%$ of the irrigation water requirements were the most satisfactory treatments for exhibiting the most favorable vegetative growth, highest yield as well as tuber quality for potato cv. Spunta planted in Al-Aqwaz, Giza Governorate or any other similar areas.
\end{abstract}

Keywords: potato, planting dates, irrigation, growth, yield, tubers quality

\section{INTRODUCTION}

Potato is one of the most important crops that provide energy and nutrients to humans especially in the low-income countries (Jansky et al., 2019). Concerning potato production, Egypt is occupied the first position in Africa with total production estimated by $4,896,476$ ton in 2018 (FAOSTAT)

It is now clear to state that the climatic changes all over the world have become a truth, and this is not possible to misjudge its negative impact on the agricultural sector as well as other social and economic activities, which cannot be underestimated (Omran, 2020).

According to the investigations of GRiSP project that monitoring the Egyptian climatic changes, it is apparent that there is a significant rise in the average of maximum temperature all over Egypt, which estimated by $0.6{ }^{\circ} \mathrm{C}$ and $0.4{ }^{\circ} \mathrm{C}$ in winter and summer, respectively. Also, they stated that the short dry season, which started in August, has shifted to July, which may lead to shift the starts of other climate seasons (Bouman, 2013). Moreover, it is expected that the average of annual temperature in Egypt will be raised about $1{ }^{\circ} \mathrm{C}$ by 2030 (Agrawala et al., 2004).

Consequently, there are many changes in agricultural practices should be considered in response to changes in climate conditions (Omran, 2020). The well-known agriculture practices that subjected to modification due to the climatic changes are planting dates and irrigation requitements (Kang et al., 2009); especially, the planting dates of potato and other crops (Hijmans, 2003; Sacks et al., 2010). There were many literatures discussed the different effects of planting date on the performances of many crops, particularly potato (Ezekiel and Bhargava, 1992; Mansour and Abu El-Fotoh, 2018; Muhammad et al., 2018; Patel et al., 2018). It could be concluded from these studies that the significance of the effect of potato planting date is related to the geographical location in which the experiment is carried out in addition to the used potato cultivar(s).

The changing in planting date, consequently, should modify many other agricultural practices such as irrigation, fertilization, ... etc. that should be take into consideration (Andarzian et al., 2015). Irrigation is well known to be the vital agricultural practice that significantly affect the growth, nutrient uptake, all of physiological process, quantity and quality of yield and its components of the potato plant (Nunes et al., 2006; Kumar et al., 2018; Mankotia and Sharma, 2020). This sensitivity of potato to irrigation quantity may be due to its shallow root zone. Also, the soil in which potatoes are usually produced in medium- to coarsetextured, which is characterized by low water holding capacity (King et al., 2020).
DOI: 10.21608/asejaiqjsae.2021.189714

${ }^{1}$ Horticulture Dept., Faculty of Agriculture, Ain Shams University, Cairo, Egypt. Email: dr_noura@agr.asu.edu.eg

${ }^{2}$ Horticulture Dept., Faculty of Agriculture, Damanhour University, Damanhour, Egypt. Email: alaa.roshdy@agr.dmu.edu.eg

ORCID: https://orcid.org/0000-0002-9236-1019

Received July 10, 2021, Accepted, August 11, 2021. 
The aim of this study was to examine the effect of different three planting dates and three levels of irrigation regimes on the growth, tuber yield and the chemical quality of the tubers of potato "Spunta" cultivar.

\section{MATERIAL AND METHODS}

Field experiment was carried out in privet farm in Al-Aqwaz, Giza Governorate (Latitude $29^{\circ} 36^{\prime} \mathrm{N}$, Longitude $31^{\circ} 16^{\prime} \mathrm{E}$ ) in of sandy loam soil to study the effect of planting dates and irrigation levels and their interaction on growth, yield and chemical quality of potato tubers during two successive seasons of 2018/2019 and 2019/2020. The meteorological data during this period are listed in Table 1.

\section{Treatments}

The examined treatments in this investigation included two main factors as follows:

- Planting date: Three planting dates were selected, which were the $1^{\text {st }}$ of December, $15^{\text {th }}$ of December and $1^{\text {st }}$ of January, which were symbolized as $\mathrm{PD}_{1}$, $\mathrm{PD}_{2}$, and $\mathrm{PD}_{3}$, respectively.

Irrigation regime: three selected irrigation regimes: 50,75 and $100 \%$ of the irrigation requirements for each of the selected planting date, which were symbolized as $\mathrm{IR}_{50 \%}, \mathrm{IR}_{75 \%}$, and $\mathrm{IR}_{100 \%}$, respectively.

Drip irrigation system was applied. The different irrigation treatments were controlled by manual valves for each hose on the top of the lines in the experimental plot. For each planting date, the total amounts of water for each irrigation treatment in the two seasons are shown in Table 2, which was calculated according to the method stated by Food and Agriculture Organization (FAO) according to Allen et al. (1998).

\section{Experimental layout and planting}

The experimental design was complete block design in split-plot arrangement with three replicates, in which the main plots were devoted to planting dates and the irrigation treatments occupied the sub-plots. The total area of each sub-plot was $14 \mathrm{~m}^{2}$ included four rows with $5 \mathrm{~m}$ long and $70 \mathrm{~cm}$ width for each. Local produced certified potato seed cv. Spunta, with an average size of 100-150 g were obtained from Agric. Res. Center (ARC), Ministry of Agriculture and Land Reclamation (MALR) were planted at different planting dates, a guard row was left between each two sub-plots to protect against interferences.

\section{Recorded data}

\section{Vegetative growth}

After 85 days of planting, the plant height was recorded, from the base to the terminal growing point. The average number of each of main stems and leaves were calculated as an average of three plants. The main stems diameter was measured using caliper. The potato leaf chlorophyll was determined in situ using SPAD502 chlorophyll meter (Markwell et al., 1995).

\section{Tuber chemical composition}

The nitrogen, phosphorus, potassium and calcium of the potato tubers were determined according to the laboratory manual of Estefan et al. (2013) where the $\mathrm{N}$ content was estimated by Kjeldahl method, each of P, K and $\mathrm{Ca}$ was determined spectrophotometrically.

\section{Yield and tuber quality}

Total tuber yield was calculated by weighing the yield of the plot, then converted into tons per hectare. Concerning the quality properties of potato tubers, the specific gravity of tubers was determined using the equation of Kleinschmidt and Kleinkopf (1984) as follows:

Specific Gravity (SG) =Tuber weight in air/(tuber weight in the air - tuber weight in water)

For determination of dry matter percentage, three whole tubers were randomly selected from each treatment and their fresh weight was measured. After that, the potato tuber samples were cut into small slices, and dryied at $70^{\circ} \mathrm{C}$ for $72 \mathrm{~h}$ in a forced air oven. The dry weight of samples was measured. The following formula was used for determining dry matter percentage (DM\%):

Dry matter $(\%)=($ dry weight $/$ fresh weight $) \times 100$

The crude protein of potato tuber was calculated by multiplying the nitrogen content with the factor of 6.25 (Van Gelder, 1981). The potato tuber starch content was estimated as percentage in dry matter basis by the method of Vainio (1968)

\section{Statistical analyses}

All the optained data were statistically analyzed using CoStat program (COSTAT, 2005). Least Significant Difference test (LSD) was used at 0.05 confidence level to verify the significance between treatments by using the same program.

\section{RESULTS AND DISCUSSION}

\section{Vegetative growth characters}

Plants grown during the first planting date or irrigated with the high irrigation requirements produced the highest values of plant height, main stem number, main stem diameter, leaf number and chlorophyll of potato $\mathrm{cv}$. 
Table 1. Monthly average rainfall $\left(\mathrm{mm} \mathrm{day}{ }^{-1}\right)$, maximum $\left(\mathbf{T}_{\mathrm{MAX}}\right)$ and minimum $\left(\mathbf{T}_{\mathrm{MIN}}\right)$ temperatures $\left({ }^{\circ} \mathrm{C}\right)$ for the two growing seasons.

\begin{tabular}{|c|c|c|c|c|c|c|c|}
\hline & \multicolumn{3}{|c|}{ 2018/2019 season } & & \multicolumn{3}{|c|}{$2019 / 2020$ season } \\
\hline & RAIN & $\mathbf{T}_{\text {MAX }}$ & $\mathbf{T}_{\text {MIN }}$ & & RAIN & $\mathbf{T}_{\text {MAX }}$ & $\mathbf{T}_{\text {MIN }}$ \\
\hline Dec-18 & 0.03 & 21.51 & 10.66 & Dec-19 & 0.05 & 23.86 & 11.58 \\
\hline Jan-19 & 0.87 & 19.75 & 8.51 & Jan-20 & 0.66 & 18.05 & 7.31 \\
\hline Feb-19 & 0.67 & 21.53 & 8.98 & Feb-20 & 0.58 & 20.65 & 8.10 \\
\hline Mar-19 & 2.33 & 25.29 & 11.07 & Mar-20 & 1.80 & 25.07 & 10.19 \\
\hline Apr-19 & 0.07 & 27.99 & 12.30 & Apr-20 & 0.06 & 29.40 & 14.18 \\
\hline May-19 & 0.00 & 36.81 & 17.83 & May-20 & 0.00 & 33.91 & 17.94 \\
\hline
\end{tabular}

Table 2. Seasonal irrigation requirements $\left(\mathrm{m}^{3} /\right.$ faddan) of different water level treatments (percentage of irrigation water requirements) for potato Spunta cultivar in 2018/2019 and 2019/2020 seasons.

\begin{tabular}{|c|c|c|c|c|c|c|c|c|}
\hline & & & & & \multirow{2}{*}{\multicolumn{4}{|c|}{$2019 / 2020$}} \\
\hline \multirow[t]{2}{*}{ Planting dates } & \multicolumn{4}{|c|}{$2018 / 2019$} & & & & \\
\hline & $50 \%$ & $75 \%$ & $100 \%$ & Mean & $50 \%$ & $75 \%$ & $100 \%$ & Mean \\
\hline $1^{\text {st }}$ Dec. & 564.8 & 622.4 & 778 & 655.06 & 588.9 & 751.9 & 814.9 & 718.56 \\
\hline $15^{\text {Th }}$ Dec. & 518.9 & 758.3 & 948.2 & 741.8 & 714.4 & 819.2 & 1024 & 852.53 \\
\hline $1^{\text {st }} \mathrm{Jan}$. & 779.2 & 905.9 & 1132.1 & 939.91 & 735.0 & 980.9 & 1226.1 & 980.9 \\
\hline Mean & 620.96 & 762.2 & 952.8 & & 679.43 & 850.66 & 1021.6 & \\
\hline
\end{tabular}

Spunta (Table 3) the interaction between both treatments gave the highest significant mean values of the studied vegetative growth and chlorophyll characters, in both seasons.

Plants grown during the third planting date and/or received the low irrigation requirements gave the lowest values of plant growth and chlorophyll characters in both seasons.

These findings refer to that the planting date significantly affected the growth parameters of potato plants and the planting date of $1^{\text {st }}$ December $\left(\mathrm{PD}_{1}\right)$ is the most suitable planting date more than the ordinary planting date of $15^{\text {th }}$ December $\left(\mathrm{PD}_{2}\right)$. Many other researchers stated the effect of planting dates on growth attributes (Thongam et al., 2017; Mansour and Abu ElFotoh, 2018; Patel et al., 2018; Meligy et al., 2020). However, the exact planting date is strongly related to the geographical location.

Moreover, the potato plants were found to be more affected by irrigation regimes, which was reflected on their recorded vegetative growth characters. These results are in agreement with those of King et al. (2020) and Fabeiro et al. (2001). Under the climatic conditions of this experiment, the irrigation requirements of potato must not be decreased the at all planting dates because the rainfall in this period cannot reinforce the irrigation regime of potato plants with considerable quantities of water which supposed to complete with irrigation (Table 1). Moreover, the obtained experiment results came to the harmony with those of Maralian et al.
(2017); Mansour and Abu El-Fotoh (2018); Ali et al. (2019) and Meligy et al. (2020) who showed that that the $100 \%$ of irrigation requirements gave the highest mean values of plant growth and chlorophyll content.

\section{Tuber chemical composition}

In Table 4, showed that the main effects of PDs and IRs were significant for all chemical composition traits e.g., nitrogen, phosphorus, potassium and calcium in potato tubers. Among the PD treatments, it was clear that the $\mathrm{PD}_{1}$ treatment resulted in the highest significant mean values of all of the studied elemental composition traits of potato tubers, which was in contrast with those of $\mathrm{PD}_{3}$, which gave the lowest mean values, in both seasons of study. the $\mathrm{PD}_{1}$ treatment was resulted in increment percentages of $13.80 \%, 21.69 \%, 7.71 \%$, and $19.89 \%$ for each of tuber's nitrogen, phosphorus, potassium, and calcium, respectively as an average of both seasons. As an interpretation of increasing the growth parameters when planted on $1^{\text {st }}$ December $\left(\mathrm{DP}_{1}\right)$, the chemical composition of potato tubers exhibited the highest mean values at the same date comparing with other tested planting dates.

Concerning the IR treatments (Table 4), the full application of IR was found to give significant the highest tubers contents of nitrogen phosphorus, potassium and calcium comparing with the other IR treatments, in both seasons. 
Table 3. The effect of planting dates and irrigation levels on growth chracters and chlorophyll of potato c.v. "Spunta" in 2018/2019 and 2019/2020 seasons.

\begin{tabular}{|c|c|c|c|c|c|c|c|c|}
\hline \multirow{4}{*}{$\begin{array}{l}\text { Irrigation } \\
\text { regimes }\end{array}$} & \multicolumn{8}{|c|}{ Planting Dates } \\
\hline & \multicolumn{4}{|c|}{ 2018/2019 } & \multicolumn{4}{|c|}{$2019 / 2020$} \\
\hline & PD1 & $\mathbf{P D}_{2}$ & $\mathbf{P D}_{3}$ & Mean & PD1 & $\mathbf{P D}_{2}$ & PD3 & Mean \\
\hline & \multicolumn{8}{|c|}{ Plant height $(\mathrm{cm})$} \\
\hline $\mathrm{IR}_{50 \%}$ & $41.41 \mathrm{de}$ & $37.65 \mathrm{e}$ & $33.02 \mathrm{f}$ & $37.36 \mathrm{C}$ & $38.64 \mathrm{de}$ & $37.53 \mathrm{ef}$ & $34.90 \mathrm{f}$ & $37.03 \mathrm{C}$ \\
\hline $\mathrm{IR}_{75 \%}$ & $48.67 \mathrm{ab}$ & $44.10 \mathrm{~cd}$ & $34.14 \mathrm{ef}$ & $43.30 \mathrm{~B}$ & $46.81 \mathrm{~b}$ & $43.59 \mathrm{c}$ & $40.53 d$ & 43.64B \\
\hline $\mathrm{IR}_{100 \%}$ & $52.48 \mathrm{a}$ & $46.74 \mathrm{bc}$ & $41.35 \mathrm{de}$ & $46.85 \mathrm{~A}$ & $50.61 \mathrm{a}$ & $46.33 \mathrm{bc}$ & $44.98 \mathrm{bc}$ & $47.31 \mathrm{~A}$ \\
\hline \multirow[t]{2}{*}{ Mean } & $47.52 \mathrm{~A}$ & $42.83 \mathrm{~B}$ & $37.17 \mathrm{C}$ & & $45.36 \mathrm{~A}$ & $42.48 \mathrm{~B}$ & $40.14 \mathrm{C}$ & \\
\hline & \multicolumn{8}{|c|}{ Main stem number } \\
\hline $\mathrm{IR}_{50 \%}$ & $3.00 \mathrm{c}$ & $3.00 \mathrm{c}$ & $3.00 \mathrm{c}$ & $3.00 \mathrm{C}$ & $2.67 \mathrm{c}$ & $2.67 \mathrm{c}$ & $2.67 \mathrm{c}$ & $2.66 \mathrm{C}$ \\
\hline $\mathrm{IR}_{75 \%}$ & $4.00 \mathrm{ab}$ & $3.33 b c$ & $3.00 \mathrm{c}$ & $3.44 \mathrm{~B}$ & $3.67 \mathrm{a}-\mathrm{c}$ & $3.00 \mathrm{bc}$ & $3.33 \mathrm{a}-\mathrm{c}$ & $3.33 \mathrm{~B}$ \\
\hline $\mathrm{IR}_{100 \%}$ & $4.00 \mathrm{ab}$ & $4.00 \mathrm{ab}$ & $4.33 \mathrm{a}$ & $4.11 \mathrm{~A}$ & $4.00 \mathrm{ab}$ & $3.67 \mathrm{a}-\mathrm{c}$ & $4.33 \mathrm{a}$ & $4.00 \mathrm{~A}$ \\
\hline \multirow[t]{2}{*}{ Mean } & $3.67 \mathrm{~A}$ & $3.44 \mathrm{~A}$ & $3.44 \mathrm{~A}$ & & $3.44 \mathrm{~A}$ & $3.44 \mathrm{~A}$ & $3.11 \mathrm{~A}$ & \\
\hline & \multicolumn{8}{|c|}{ Main stem diameter (mm) } \\
\hline $\mathrm{IR}_{50 \%}$ & $14.30 \mathrm{c}$ & $13.27 \mathrm{de}$ & $13.17 \mathrm{e}$ & $13.58 \mathrm{C}$ & $13.78 b c$ & $12.96 \mathrm{c}$ & $12.85 \mathrm{c}$ & $13.20 \mathrm{C}$ \\
\hline $\mathrm{IR}_{75 \%}$ & $16.04 \mathrm{a}$ & $15.00 \mathrm{bc}$ & $14.25 \mathrm{~cd}$ & 15.10B & $15.57 \mathrm{ab}$ & $14.57 \mathrm{ab}$ & $13.74 \mathrm{bc}$ & $14.63 B$ \\
\hline $\mathrm{IR}_{100 \%}$ & $16.08 \mathrm{a}$ & $16.01 \mathrm{a}$ & $15.46 \mathrm{ab}$ & $15.84 \mathrm{~A}$ & $15.58 \mathrm{a}$ & $15.41 \mathrm{a}$ & $15.13 \mathrm{a}$ & $15.37 \mathrm{~A}$ \\
\hline \multirow[t]{2}{*}{ Mean } & $15.48 \mathrm{~A}$ & $14.76 \mathrm{AB}$ & $14.29 \mathrm{~B}$ & & $14.98 \mathrm{~A}$ & $14.31 \mathrm{AB}$ & 13.91B & \\
\hline & \multicolumn{8}{|c|}{ Leaf number } \\
\hline $\mathrm{IR}_{50 \%}$ & $62.35 \mathrm{bc}$ & $59.89 \mathrm{bc}$ & $56.42 \mathrm{c}$ & $59.55 \mathrm{C}$ & $60.22 \mathrm{de}$ & $59.52 \mathrm{ef}$ & $53.68 \mathrm{f}$ & $57.81 \mathrm{C}$ \\
\hline $\mathrm{IR}_{75 \%}$ & $83.67 \mathrm{a}$ & $65.67 \mathrm{~b}$ & $62.36 \mathrm{bc}$ & $70.56 \mathrm{~B}$ & $79.67 \mathrm{ab}$ & $65.67 \mathrm{~cd}$ & $63.00 \mathrm{c}-\mathrm{e}$ & $69.44 \mathrm{~B}$ \\
\hline $\mathrm{IR}_{100 \%}$ & $85.00 \mathrm{a}$ & $81.33 \mathrm{a}$ & $65.02 \mathrm{~b}$ & $77.12 \mathrm{~A}$ & $85.33 \mathrm{a}$ & $75.33 b$ & $67.67 \mathrm{c}$ & $79.11 \mathrm{~A}$ \\
\hline \multirow[t]{2}{*}{ Mean } & $77.00 \mathrm{~A}$ & $68.96 \mathrm{~B}$ & $61.27 \mathrm{C}$ & & $75.07 \mathrm{~A}$ & $66.84 \mathrm{~B}$ & $61.45 \mathrm{C}$ & \\
\hline & \multicolumn{8}{|c|}{ Chlorophyll (SPAD) } \\
\hline $\mathrm{IR}_{50 \%}$ & $50.29 \mathrm{bc}$ & $45.90 \mathrm{~d}$ & $41.59 \mathrm{e}$ & $45.93 \mathrm{C}$ & $47.33 b-e$ & $46.00 \mathrm{c}-\mathrm{e}$ & $43.33 \mathrm{e}$ & $45.56 \mathrm{C}$ \\
\hline $\mathrm{IR}_{75 \%}$ & $53.95 \mathrm{ab}$ & $51.05 \mathrm{bc}$ & $45.35 \mathrm{de}$ & $50.12 B$ & $51.33 \mathrm{ab}$ & $48.67 b-d$ & $45.67 \mathrm{de}$ & $48.56 \mathrm{~B}$ \\
\hline $\mathrm{IR}_{100 \%}$ & $57.57 \mathrm{a}$ & $52.64 b$ & $47.89 \mathrm{~cd}$ & $52.70 \mathrm{~A}$ & $54.32 \mathrm{a}$ & $51.33 \mathrm{ab}$ & $50.25 a-c$ & $51.97 \mathrm{~A}$ \\
\hline Mean & 53.94A & $49.86 \mathrm{~B}$ & $44.94 \mathrm{C}$ & & $51.00 \mathrm{~A}$ & 48.67B & $46.42 \mathrm{C}$ & \\
\hline
\end{tabular}

*The mean values with the same letters do not differ significantly at 0.05 level.

This preference for $\mathrm{IR}_{100 \%}$ treatment was more apparent by calculating the percentages of increase in the mean values of these characters than of those corresponding in $\mathrm{IR}_{50 \%}$ treatment, which was estimated by $31.24 \%$ for nitrogen, $45.46 \%$ for phosphorus, $23.84 \%$ for potassium and $48.61 \%$ for calcium, as an average of both seasons.

The effect of planting dates and irrigation regimes on chemical composition of potato was also reported by Nunes et al. (2006); Mansour and Abu El-Fotoh (2018); Ali et al. (2019) and Mankotia and Sharma (2020). Moreover, it could be noticed that the increment percentages of most of studied characters due to $\mathrm{IR}_{100 \%}$ were found to be higher than those of due $\mathrm{PD}_{1}$, which could be due to the vital and well-known role of availability of soil moisture for increasing absorbtion by plant roots (Marschner and Rengel, 2011). Also, the decrease of absorbed of water causing decline in all physiological processes in plant (Fathi and Tari, 2016).
It clear that the potato tuber nutrient contents were significantly decreased linearly with decreasing the amount of irrigation water. Also, the results revealed that the highest decreases were found with phosphorus and calcium. Concerning the phosphorus shortage under $\mathrm{IR}_{50 \%}$, it could be due to that the phosphorus is immobile nutrient element in soil and strongly dependent on the degree of the moisture availability in soil where the ability of phosphorus acquisition by plant root declined significantly due to moisture decreasing (Sun et al., 2015). The high decline of calcium content in tubers could be due to that calcium is transmitted entirely through the transpiration flow of plants, which depends on the amount of water absorbed by the plant's roots (Vos and Haverkort, 2007).

The interaction between PDs and IRs, which was found to have significant influence on potato tubers content of nitrogen phosphorus, potassium and calcium, in both seasons of study. 
Table 4. The main effects of planting dates and irrigation levels and their interaction on nitrogen, phosphorus, potassium and calcium of potato c.v. "Spunta" tubers in 2018/2109 and 2019/2020 seasons.

\begin{tabular}{|c|c|c|c|c|c|c|c|c|}
\hline \multirow{3}{*}{$\begin{array}{c}\text { Irrigation } \\
\text { regimes }\end{array}$} & \multicolumn{8}{|c|}{ Planting Dates } \\
\hline & \multicolumn{4}{|c|}{$2018 / 2019$} & \multicolumn{4}{|c|}{$2019 / 2020$} \\
\hline & $\mathbf{P D}_{1}$ & $\mathbf{P D}_{2}$ & PD $3_{3}$ & Mean & $\mathbf{P D}_{1}$ & $\mathbf{P D}_{2}$ & $\mathbf{P D}_{3}$ & Mean \\
\hline & \multicolumn{8}{|c|}{ Nitrogen (\%) } \\
\hline $\mathrm{IR}_{50 \%}$ & $2.01 \mathrm{~d}$ & $1.64 \mathrm{e}$ & $1.56 \mathrm{e}$ & $1.74 \mathrm{C}$ & $2.04 \mathrm{c}$ & $1.81 \mathrm{~d}$ & $1.71 \mathrm{e}$ & $1.85 \mathrm{C}$ \\
\hline $\mathrm{IR}_{75 \%}$ & $2.35 b$ & $2.23 \mathrm{c}$ & $2.05 \mathrm{~d}$ & $2.21 \mathrm{~B}$ & $2.35 b$ & $2.11 \mathrm{c}$ & $2.06 \mathrm{c}$ & $2.17 \mathrm{~B}$ \\
\hline $\mathrm{IR}_{100 \%}$ & $2.67 \mathrm{a}$ & $2.71 \mathrm{a}$ & $2.44 b$ & $2.60 \mathrm{~A}$ & $2.74 \mathrm{a}$ & $2.74 a$ & $2.39 b$ & $2.62 \mathrm{~A}$ \\
\hline \multirow[t]{2}{*}{ Mean } & $2.34 \mathrm{~A}$ & $2.19 \mathrm{~B}$ & $2.01 \mathrm{C}$ & & $2.37 \mathrm{~A}$ & $2.21 \mathrm{~B}$ & $2.05 \mathrm{C}$ & \\
\hline & \multicolumn{8}{|c|}{ Phosphorus (\%) } \\
\hline $\mathrm{IR}_{50 \%}$ & $0.29 \mathrm{ef}$ & $0.27 \mathrm{fg}$ & $0.24 \mathrm{~g}$ & $0.26 \mathrm{C}$ & $0.21 \mathrm{de}$ & $0.17 f$ & $0.12 \mathrm{~g}$ & $0.17 \mathrm{C}$ \\
\hline $\mathrm{IR}_{75 \%}$ & $0.38 \mathrm{c}$ & $0.35 \mathrm{~d}$ & $0.31 \mathrm{e}$ & $0.34 \mathrm{~B}$ & $0.29 \mathrm{c}$ & $0.24 \mathrm{~d}$ & $0.20 \mathrm{ef}$ & $0.24 \mathrm{~B}$ \\
\hline $\mathrm{IR}_{100 \%}$ & $0.47 \mathrm{a}$ & $0.43 b$ & $0.41 b c$ & $0.44 \mathrm{~A}$ & $0.38 \mathrm{a}$ & $0.34 \mathrm{~b}$ & $0.30 \mathrm{c}$ & $0.34 \mathrm{~A}$ \\
\hline \multirow[t]{2}{*}{ Mean } & $0.38 \mathrm{~A}$ & $0.35 \mathrm{~B}$ & $0.32 \mathrm{C}$ & & $0.29 \mathrm{~A}$ & $0.25 \mathrm{~B}$ & $0.21 \mathrm{C}$ & \\
\hline & \multicolumn{8}{|c|}{ Potassium (\%) } \\
\hline $\mathrm{IR}_{50 \%}$ & $2.73 d$ & $2.57 \mathrm{e}$ & $2.51 \mathrm{e}$ & $2.60 \mathrm{C}$ & $2.32 \mathrm{~d}$ & $2.23 \mathrm{~d}$ & $2.05 \mathrm{e}$ & $2.20 \mathrm{C}$ \\
\hline $\mathrm{IR}_{75 \%}$ & $3.27 \mathrm{~b}$ & $3.13 \mathrm{c}$ & $3.04 \mathrm{c}$ & $3.15 \mathrm{~B}$ & $2.75 b$ & $2.57 \mathrm{c}$ & $2.48 \mathrm{c}$ & $2.60 \mathrm{~B}$ \\
\hline $\mathrm{IR}_{100 \%}$ & $3.49 \mathrm{a}$ & $3.54 \mathrm{a}$ & $3.36 \mathrm{~b}$ & $3.46 \mathrm{~A}$ & $2.91 \mathrm{a}$ & $2.94 \mathrm{a}$ & $2.71 b$ & $2.85 \mathrm{~A}$ \\
\hline \multirow[t]{2}{*}{ Mean } & $3.16 \mathrm{~A}$ & $3.08 \mathrm{~B}$ & $2.97 \mathrm{C}$ & & $2.66 \mathrm{~A}$ & $2.58 \mathrm{~B}$ & $2.41 \mathrm{C}$ & \\
\hline & \multicolumn{8}{|c|}{ Calcium (\%) } \\
\hline $\mathrm{IR}_{50 \%}$ & $0.79 \mathrm{c}$ & $0.61 d$ & $0.48 \mathrm{e}$ & $0.63 \mathrm{C}$ & $0.58 \mathrm{~d}$ & $0.56 \mathrm{~d}$ & $0.44 \mathrm{e}$ & $0.53 \mathrm{C}$ \\
\hline $\mathrm{IR}_{75 \%}$ & $0.96 b$ & $0.78 \mathrm{c}$ & $0.77 \mathrm{c}$ & $0.84 \mathrm{~B}$ & $0.80 \mathrm{c}$ & $0.73 c$ & $0.80 \mathrm{c}$ & $0.78 \mathrm{~B}$ \\
\hline $\mathrm{IR}_{100 \%}$ & $1.31 \mathrm{a}$ & $1.25 \mathrm{a}$ & $0.95 b$ & $1.17 \mathrm{~A}$ & $1.16 \mathrm{a}$ & $1.10 \mathrm{a}$ & $0.97 \mathrm{~b}$ & $1.08 \mathrm{~A}$ \\
\hline Mean & $1.02 \mathrm{~A}$ & $0.88 \mathrm{~B}$ & $0.73 \mathrm{C}$ & & $0.85 \mathrm{~A}$ & $0.80 \mathrm{~B}$ & $0.74 \mathrm{C}$ & \\
\hline
\end{tabular}

* The mean values with the same letters do not differ significantly at 0.05 level.

Also, the interaction between $\mathrm{PD}_{1}$ and $\mathrm{IR}_{100 \%}$ gave the most favorable increases in tuber chemical composition comparing with $\mathrm{PD}_{3}$ and $\mathrm{IR}_{50 \%}$ interaction, in both seasons of study. Moreover, it was found that the highest interaction of $\mathrm{PD}_{1}+\mathrm{IR}_{100 \%}$ increased the average of both seasons mean-values of nitrogen, phosphorus, potassium, and calcium by $39.58 \%, 55.49 \%, 28.82 \%$, and $64.20 \%$, respectively when compared with the corresponding interaction mean-values of $\mathrm{PD}_{3}+\mathrm{IR}_{50} \%$ that gave the lowest interaction mean values.

\section{Yield and its quality}

According to the mean values of main factors of PDs and IRs (Table 5), there is a clear significant effect of these treatments on all yield and its quality characters of potato tubers, in both seasons. Also, each of $\mathrm{PD}_{1}$ or $\mathrm{IR}_{100 \%}$ exhibited the highest mean values of tubers yield, specific gravity, as well as dry matter, protein and starch percentages, in both seasons of study. Moreover, the potato tubers yield was found to be the most responsive trait to these treatments that were evident in the average percentage increase, which was estimated by $35.44 \%$ under $\mathrm{PD}_{1}$ treatment and by $42.33 \%$ under $\mathrm{IR}_{100 \%}$ treatment when compared with corresponded mean values of $\mathrm{PD}_{3}$ and $\mathrm{IR}_{50 \%}$, as an average of both seasons of study. The results of this context are in agreement with the results of Thongam et al. (2017); Patel et al. (2018) and Meligy et al. (2020). Moreover, Fabeiro et al. (2001) published that in semi-arid climates, the different potato attributes are significantly responded to the amount of irrigation water. In addition, each of King et al. (2020) and Fabeiro et al. (2001) pointed out that the irrigation amounts reflects on growth and nutrients absorption, which exhibited on yield and quality of potato tubers. In addition, Yenagi et al. (2010) found significant variation between characters in response to planting dates due to an advantage of favorable environmental factors for potato yield and its quality traits.

In the case of interaction between planting dates and irrigation regimes on potato tuber yield and its quality characters, the mean values (Table 5) illustrated significant effect of such interaction on all of the characters, in both seasons of study. Also, the most favorable interaction was found to be between $\mathrm{PD}_{1}$ with $\mathrm{IR}_{100 \%}$ comparing with the other combination treatments. 
Table 5. The main effects of planting dates and irrigation levels and their interaction on yield, specific gravity, dry matter, protein and starch of potato c.v. "Spunta" tubers in 2018/2109 and 2019/2020 seasons.

\begin{tabular}{|c|c|c|c|c|c|c|c|c|}
\hline \multirow{4}{*}{$\begin{array}{l}\text { Irrigation } \\
\text { regimes }\end{array}$} & \multicolumn{8}{|c|}{ Planting Dates } \\
\hline & \multicolumn{4}{|c|}{$2018 / 2019$} & \multicolumn{4}{|c|}{$2019 / 2020$} \\
\hline & PD1 $_{1}$ & $\mathbf{P D}_{2}$ & $\mathrm{PD}_{3}$ & Mean & $\mathbf{P D}_{1}$ & $\mathbf{P D}_{2}$ & $\mathrm{PD}_{3}$ & Mean \\
\hline & \multicolumn{8}{|c|}{ Yield (ton ha' ha $^{-1}$} \\
\hline $\mathrm{IR}_{50 \%}$ & $22.92 \mathrm{ef}$ & $19.02 \mathrm{~g}$ & $15.14 \mathrm{~h}$ & $19.04 \mathrm{C}$ & $17.14 \mathrm{de}$ & $14.95 f$ & $11.35 \mathrm{~g}$ & $14.47 \mathrm{C}$ \\
\hline $\mathrm{IR}_{75 \%}$ & $31.89 \mathrm{~b}$ & $23.75 \mathrm{de}$ & $20.94 \mathrm{fg}$ & $25.54 \mathrm{~B}$ & $27.30 \mathrm{~b}$ & $18.52 \mathrm{~d}$ & $15.95 \mathrm{ef}$ & $20.59 \mathrm{~B}$ \\
\hline $\mathrm{IR}_{100 \%}$ & $38.06 \mathrm{a}$ & $28.23 \mathrm{c}$ & $25.35 \mathrm{~d}$ & $30.54 \mathrm{~A}$ & $33.34 \mathrm{a}$ & $23.01 \mathrm{c}$ & $21.71 \mathrm{c}$ & $26.01 \mathrm{~A}$ \\
\hline \multirow[t]{2}{*}{ Mean } & $30.96 \mathrm{~A}$ & $23.66 \mathrm{~B}$ & $20.49 \mathrm{C}$ & & $25.94 \mathrm{~A}$ & $18.83 \mathrm{~B}$ & $16.33 \mathrm{C}$ & \\
\hline & \multicolumn{8}{|c|}{ Specific gravity $\left(\mathrm{g} \mathrm{cm}^{-3}\right)$} \\
\hline $\mathrm{IR}_{50 \%}$ & $1.20 \mathrm{~b}$ & $1.08 \mathrm{~d}$ & $0.98 \mathrm{f}$ & $1.09 \mathrm{C}$ & $1.08 \mathrm{~cd}$ & $1.02 \mathrm{~d}$ & $0.95 \mathrm{e}$ & $1.02 \mathrm{C}$ \\
\hline $\mathrm{IR}_{75 \%}$ & $1.23 \mathrm{~b}$ & $1.13 \mathrm{c}$ & $1.04 \mathrm{e}$ & $1.13 \mathrm{~B}$ & $1.6 \mathrm{ab}$ & $1.06 \mathrm{~cd}$ & $1.04 \mathrm{~d}$ & $1.09 \mathrm{~B}$ \\
\hline $\mathrm{IR}_{100 \%}$ & $1.28 \mathrm{a}$ & $1.15 \mathrm{c}$ & $1.05 \mathrm{e}$ & $1.16 \mathrm{~A}$ & $1.21 \mathrm{a}$ & $1.11 \mathrm{bc}$ & $1.07 \mathrm{~cd}$ & $1.13 \mathrm{~A}$ \\
\hline \multirow[t]{2}{*}{ Mean } & $1.23 \mathrm{~A}$ & $1.12 \mathrm{~B}$ & $1.09 \mathrm{C}$ & & $1.15 \mathrm{~A}$ & $1.06 \mathrm{~B}$ & $1.02 \mathrm{C}$ & \\
\hline & \multicolumn{8}{|c|}{ Dry matter (\%) } \\
\hline $\mathrm{IR}_{50 \%}$ & $21.83 b-d$ & $20.50 \mathrm{de}$ & $19.25 \mathrm{e}$ & $20.53 \mathrm{C}$ & $22.28 b c$ & $19.14 d$ & $16.99 \mathrm{e}$ & $19.47 \mathrm{C}$ \\
\hline $\mathrm{IR}_{75 \%}$ & $23.33 \mathrm{ab}$ & $22.56 b c$ & $20.97 \mathrm{~cd}$ & $22.29 \mathrm{~B}$ & $23.21 \mathrm{~b}$ & $20.65 \mathrm{~cd}$ & $18.80 \mathrm{de}$ & $20.89 \mathrm{~B}$ \\
\hline $\mathrm{IR}_{100 \%}$ & $24.88 \mathrm{a}$ & $23.39 \mathrm{ab}$ & $21.61 \mathrm{~cd}$ & $23.30 \mathrm{~A}$ & $25.58 \mathrm{a}$ & $22.76 b$ & $18.81 \mathrm{de}$ & $22.39 \mathrm{~A}$ \\
\hline \multirow[t]{2}{*}{ Mean } & $23.34 \mathrm{~A}$ & $22.15 B$ & $20.61 \mathrm{C}$ & & $23.69 \mathrm{~A}$ & $20.85 B$ & $18.20 \mathrm{C}$ & \\
\hline & \multicolumn{8}{|c|}{ Protein $(\%)$} \\
\hline $\mathrm{IR}_{50 \%}$ & $12.59 \mathrm{~d}$ & $10.23 \mathrm{e}$ & $9.75 \mathrm{e}$ & $10.86 \mathrm{C}$ & $12.73 \mathrm{c}$ & $11.29 \mathrm{~d}$ & $10.69 \mathrm{e}$ & $11.57 \mathrm{C}$ \\
\hline $\mathrm{IR}_{75 \%}$ & $14.71 \mathrm{~b}$ & $13.92 \mathrm{c}$ & $12.79 \mathrm{~d}$ & $13.81 \mathrm{~B}$ & $14.67 \mathrm{~b}$ & $13.17 \mathrm{c}$ & $12.88 \mathrm{c}$ & $13.57 \mathrm{~B}$ \\
\hline $\mathrm{IR}_{100 \%}$ & $16.67 \mathrm{a}$ & $16.92 \mathrm{a}$ & $15.23 b$ & $16.27 \mathrm{~A}$ & $17.10 \mathrm{a}$ & $17.13 \mathrm{a}$ & $14.94 b$ & $16.39 \mathrm{~A}$ \\
\hline \multirow[t]{2}{*}{ Mean } & $14.65 \mathrm{~A}$ & $13.69 \mathrm{~B}$ & $12.59 \mathrm{C}$ & & $14.83 \mathrm{~A}$ & $13.86 \mathrm{~B}$ & $12.84 \mathrm{C}$ & \\
\hline & \multicolumn{8}{|c|}{$\operatorname{Starch}(\%)$} \\
\hline $\mathrm{IR}_{50 \%}$ & $55.45 b-d$ & $54.27 \mathrm{de}$ & $53.16 \mathrm{e}$ & $54.29 \mathrm{C}$ & $55.85 \mathrm{bc}$ & $53.06 \mathrm{~d}$ & $51.14 \mathrm{e}$ & $53.35 \mathrm{C}$ \\
\hline $\mathrm{IR}_{75 \%}$ & $56.79 \mathrm{ab}$ & $56.11 \mathrm{bc}$ & $54.68 \mathrm{~cd}$ & $55.86 \mathrm{~B}$ & $56.69 \mathrm{~b}$ & $54.41 \mathrm{~cd}$ & $52.75 \mathrm{de}$ & $54.61 \mathrm{~B}$ \\
\hline $\mathrm{IR}_{100 \%}$ & $58.18 \mathrm{a}$ & $56.85 \mathrm{ab}$ & $55.26 \mathrm{~cd}$ & $56.76 \mathrm{~A}$ & $58.8 \mathrm{a}$ & $56.28 b$ & $52.77 \mathrm{de}$ & $55.95 \mathrm{~A}$ \\
\hline Mean & $56.81 \mathrm{~A}$ & $15.74 \mathrm{~B}$ & $14.37 \mathrm{C}$ & & $57.11 \mathrm{~A}$ & $54.58 \mathrm{~B}$ & $52.22 \mathrm{C}$ & \\
\hline
\end{tabular}

* The mean values with the same letters do not differ significantly at 0.05 level.

The average increment percentages of both seasons were found to be $63.09 \%, 22.47 \%, 28.11 \%, 39.50 \%$ and $34.18 \%$ for each of tuber's yield, specific gravity, dry matter, protein and starch, respectively, compared to the interaction between the third planting date with the lowest irrigation level.

According to the interaction results, it could emphasize the importance of selecting the most suitable combination between planting dates and irrigation regimes for maximizing the profits of potato production, which varies according to the geographical location and their meteorological properties.

\section{CONCLUSION}

According to the abtained results, it could be concluded that among the tested planting dates of potato cv. Spunta, the date of $1^{\text {st }}$ December was found to be the most suitable planting date in Giza governorate or any other area similar in its mereological properties. this gives the potato farmers in these areas the ability to cultivate the Spunta potato cultivar earlier than the ordinary date of planting potato in summer season that starts from $15^{\text {th }}$ December. Also, it is not recommended to the potato farmers in Egypt to decrease the quantities of the used irrigation water.

\section{REFERENCES}

Agrawala, S., A. Moehner, M. El Raey, D. Conway, M. Van Aalst, M. Hagenstad, and J. Smith. 2004. Development and climate change in Egypt: focus on coastal resources and the Nile. Organ. Econ. Co-operation Dev. 1: 1-68.

Ali, R.A.M., M.M. Attia, A.E. Abd El-All, and C. Mark. 2019. Influence of Irrigation Treatments and Humic Acid (HA) Application on Vegetative Growth, Yield, Tuber Quality Water Requirements and Water Utilization Efficiency (WUE) of Potato Plants. J. Plant Prod. Mansoura Univ 10: 793-798.

https://doi.org/10.21608/jpp.2019.60026 
Allen, R.G., L.S. Pereira, D. Raes, and M. Smith. 1998. Crop evapotranspiration-Guidelines for computing crop water requirements-FAO Irrigation and drainage paper \#56, scscourt.org. Rome, Italy.

Andarzian, B., G. Hoogenboom, M. Bannayan, and M. Shirali, , B. Andarzian. 2015. Determining optimum sowing date of wheat using CSM-CERES-Wheat model. J. Saudi Soc. Agric. Sci. 14: 189-199.

Bouman, B. 2013. GRiSP Partnership in Motion. Los Baños (Philippines): International Rice Research Institute. 29 p.

COSTAT. 2005. Version 6.4, Copyright(c), CoHort Software, 798, Lighthouse Ave. PMB 320, Monterey, CA, 93940, U., 2005. Costat.

Estefan, G., R. Sommer, and J. Ryan. 2013. Methods of Soil, Plant, and Water Analysis: A manual for the West Asia and North Africa region, third. ed, International Center for Agricultural Research in the Dry Areas (ICARDA). International Center for Agricultural Research in the Dry Areas (ICARDA), Beirut, Lebanon.

Ezekiel, R., and S.C. Bhargava. 1992. Physiological analysis of growth of potato in relation to planting date. Indian $\mathrm{J}$. Plant Physiol. XXXV: 56-63.

Fabeiro, C., F. Martín De Santa Olalla, and J.A. De Juan. 2001. Yield and size of deficit irrigated potatoes. Agric. Water Man. 48: 255-266. https://doi.org/10.1016/S03783774(00)00129-3

Fathi, A., and D.B. Tari. 2016. Effect of Drought Stress and its Mechanism in Plants. Int. J. Life Sci. 10: 1-6. https://doi.org/10.3126/ijls.v10i1.14509

Hijmans, R.J. 2003. The effect of climate change on global potato production. Am. J. Potato Res. 80: 271-279. https://doi.org/10.1007/BF02855363

Jansky, S., R. Navarre, and J. Bamberg. 2019. Introduction to the Special Issue on the Nutritional Value of Potato. Am. J. Potato 96: 95-97. https://doi.org/10.1007/s12230-01809708-1

Kang, Y., S. Khan, and X. Ma. 2009. Climate change impacts on crop yield, crop water productivity and food security A review. Prog. Nat. Sci. 19 (12): 1665-1674 https://doi.org/10.1016/j.pnsc.2009.08.001

King, B.A., J.C. Stark, and H. Neibling. 2020. Potato Irrigation Management, in: Potato Production Systems. Springer, Switzerland, pp. 417-446.

Kleinschmidt, G., and G. Kleinkopf. 1984. Specific gravity of potatoes (CIS 609). Moscow Univ. Idaho.

Kumar, R., R. Sharma, and S.K. Bhatia. 2018. Effect of irrigation and Fertigation levels on growth and yield of potato. IJCS 6: 1458-1462.

Mankotia, S., and S. Sharma. 2020. Potato (Solanum tuberosum L.) Yield, NPK Concentration and Uptake as Influenced by Variable Levels of Drip Irrigation and Fertigation. Int. J. Curr. Microbiol. App. Sci. 9: 12771289.
Mansour, F., and H. Abu El-Fotoh. 2018. Effect of planting date, irrigation level and foliar spraying with calcium and boron treatments on potato 1. Plant growth, plant water relationship and plant chemical constituents. J. Prod. Dev. 23: 755-788. https://doi.org/10.21608/jpd.2018.42623

Maralian, H., S. Nasrollahzadeh, and Nasrollahzadeh, -Safar. 2017. Effect of limited irrigation on potato yield and chlorophyll content, in: 1st International and 5th National Conference on Organic vs. Convetional Agriculture. pp. $1-5$.

Markwell, J., J.C. Osterman, and J.L. Mitchell. 1995. Calibration of the Minolta SPAD-502 leaf chlorophyll meter. Photosynth. Res. 46: 467-472. https://doi.org/10.1007/BF00032301

Marschner, P., and Z. Rengel. 2011. Nutrient Availability in Soils, in: Marschner's Mineral Nutrition of Higher Plants. Elsevier Ltd., pp. 315-330. https://doi.org/10.1016/B9780-12-384905-2.00012-1

Meligy, M., A. Abou-Hadid, M. El-Shinawy, and U. ElBehairy. 2020. Impact of Climate Change on Water Requirements and The Productivity on Potato Crop. Egypt. J. Hortic. 47: 57-68. https://doi.org/10.21608/ejoh.2020.27403.1130

Muhammad, A., I.U. Mohammed, H. Yusuf, N.M. Kwaifa, and M.U. Tanimu. 2018. Yield of Potato (Solanum tuberosum L.) as Influenced by Variety and Planting Date in the Sudan Savanna Ecological Zone of Nigeria. Int. J. Life. Sci. Sci. Res 4: 1649-1651.

Nunes, J.C.S., P.C.R. Fontes, E.F. Araújo, and C. Sediyama. 2006. Potato plant growth and macronutrient uptake as affected by soil tillage and irrigation systems. Pesqui. Agropecuária Bras. 41: 1787-1792.

Omran, E.-S.E. 2020. Exploring Changes in the Agricultural Calendar as a Response to Climate Variability in Egypt. Springer Water, pp. 249-271. https://doi.org/10.1007/9783-030-41629-4_12

Patel, C.K., S. Kumar Chongtham, and J.K. Patel. 2018. Growth, yield and productivity of potato as influenced by date of planting and genotypes. Int. J. Agric. Sci. ISSN 9107: https://doi.org/10.13140/RG.2.2.34013.26089

0975-3710.

Sacks, W.J., D. Deryng, J.A. Foley, and N. Ramankutty. 2010. Crop planting dates: an analysis of global patterns. Glob. Ecol. Biogeogr. 19: 607-620.

Sun, Y., X. Cui, and F. Liu. 2015. Effect of irrigation regimes and phosphorus rates on water and phosphorus use efficiencies in potato. Sci. Hortic. (Amsterdam). 190: 6469. https://doi.org/10.1016/j.scienta.2015.04.017

Thongam, B., A. Anil Singh, Y. Herojit Singh, A.A. Singh, A.S. Kadam, A.A. Singh, and Y.H. Singh. 2017. Influence of planting dates on growth and yield of potato (Solanum tuberosum L.). J. Pharmacogn. Phytochem. 6: 1243-1246.

Vainio, K.A. 1968. Determination of starch by iodine colorimetry. Agric. Food Sci. 40: 60-66. https://doi.org/10.23986/afsci.71700

Van Gelder, W.M.J. 1981. Conversion factor from nitrogen to protein for potato tuber protein, Potato Res. 24 (4): 423425 . 
Vos, J., and A.J. Haverkort. 2007. Water Availability and Potato Crop Performance, in: Vreugdenhil, D. (Ed.), Potato Biology and Biotechnology. Elsevier Science B.V., pp. 333-351. https://doi.org/10.1016/B978-044451018$1 / 50058-0$
Yenagi, B.S., S.S. Meli, and S.S. Angadi. 2010. Effect of row spacing, planting date and nitrogen level on tuber grade, yield and economics of potato. Karnataka J. Agric. Sci. 17: 220-223.

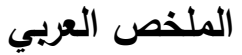

\section{النمو، الكلوروفيل، المحصول والتركيب الكميائي والجودة لارنات البطاطس صنف سبونتا متأثرا بمواعيد}

\author{
الزراعة ومقنتات الري \\ نورا محمد طه، علاء الدين حسين رشدى
}

وجود تأثيرات معنوية لمعاملات مواعيد الزراعة ومقننات الري

على جميع الصفات المقاسة في موسمي الدراسة. كما كان تأثثر مقننات الري أكثز وضوحا مقارنة بتأثير مواعيد الزراعة

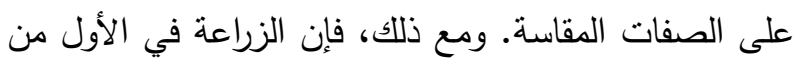
ديسمبر و /أو الري بنسبة .. 1\% من منطلبات مياه الري كانت المعاملات الأكثر نأثثرا لإظهار أفضل أداء لصنئ لصنات النمو الخضري، وأعلى إنتاجية وكذلك جودة الدرنات لصنف البطاطس اسبونتا الذي تم زراعته بالأقواز بمحافظة الجيزة أو أي مناطق أخرى ممانلة في ظروفها المناخية.

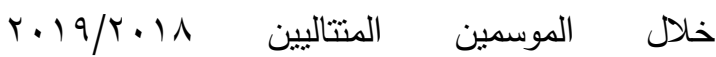

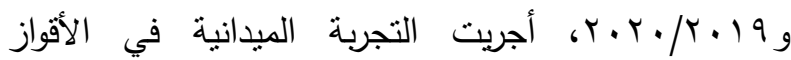
بمحافظة الجيزة بهدف دراسة تأثير ثناثة مواعيد زراعة (1)

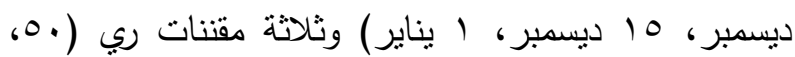
v و . . 1 ٪ من متطلبات الري لكل من تواريخ الزراعة

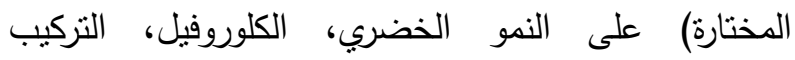

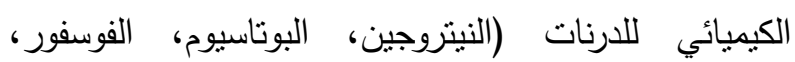
والكالسيوم)، محصول الدرنات وصفات جودتها (الجاذبية النوعية والمادة الجافة والبروتين والنشا). أظهرت النتائج 